\title{
"My People all over the World": Hip Hop, Gender, and Black Nationalism
}

\section{Natasha Distiller}

To cite this article: Natasha Distiller (2008) "My People all over the World": Hip Hop, Gender, and Black Nationalism, Safundi, 9:3, 351-356, DOI: 10.1080/17533170802172990

To link to this article: http://dx.doi.org/10.1080/17533170802172990

Published online: 17 Jul 2008.

Submit your article to this journal $\pi$

Џ Article views: 82

Q View related articles ¿ 


\title{
"My People all over the World": Hip Hop, Gender, and Black Nationalism
}

\author{
Natasha Distiller
}

\author{
Brothers Gonna Work It Out: Sexual Politics in the Golden Age of Rap \\ Nationalism \\ Charise L. Cheney \\ New York, New York University Press, 2005, pp. 222 ISBN 0-8147-1613-X
}

\section{Pimps Up, Ho's Down: Hip Hop's Hold on Young Black Women}

T. Denean Sharpley-Whiting

New York, New York University Press, 2007, pp.187 ISBN 978-0-8147-4014-9

T. Denean Sharpley-Whiting's Pimps Up, Ho's Down: Hip Hop's Hold on Young Black Women (2007) and Charise L. Cheney's Brothers Gonna Work It Out: Sexual Politics in the Golden Age of Rap Nnationalism (2005) both offer committed and informed analyses of the gender politics of a cultural movement with which their authors identify. Sharpley-Whiting's personal story prefaces her investigation into how, why, and at what cost hip hop's representations of young black women are perpetuated by these women. Cheney's investment emerges most strongly at the end of her fascinating historical foray into the form of black nationalism that she finds emerging at a particular point in the development of rap music. She calls black nationalism's true emancipatory potential into question, charging that it has failed even to "conceive [...of] a politics of liberation that is not dependent upon a masculinist discourse that incorporates a subordination of the feminine" (169). Both authors identify themselves as members of the hip hop nation they write about. What is at stake in their intellectual inquiries, then, is brought powerfully home, as each author engages with a tradition of which she is at once part, and by which she is interpolated.

Correspondence to: Natasha Distiller, Department of English Language \& Literature, University of Cape Town, Private Bag X3, Rondebosch, 7701, South Africa. Email: natasha.distiller@uct.ac.za 


\section{N. Distiller}

This reveals the importance of women engaging with the fraught race and gender politics of hip hop nationalism, by now a global force. It also makes it clear that it is possible for black women, who have endured centuries of objectification from all communities, to speak sympathetically against discourses that seek to promote black masculinity at the cost of women's subjectivity, in the face of ongoing systemic racism, while remaining sympathetic to the specific forms of systemic racism endured by black men.

Both books take as their location African America, with its specific characteristics. However, broader points about the representational and accompanying sexual violence of hip hop, in Sharpley-Whiting's case, and about the imbrication of race and gender politics in a liberation struggle, in Cheney's, are relevant to many other locations.

Pimps Up, Ho's Down takes its title from a documentary made for the United States cable channel HBO. The director's cut was released in 1999. Billed as "the definitive pimpumentary,"1 it is exemplary of the unashamedly misogynist representations of women with which Sharpley-Whiting is concerned. She argues that hip hop has made mainstream the idea that a woman's personal empowerment lies in the exploitation of her sexuality. The trope of the pimp is dominant in many hip hop videos and lyrics, with the attendant visibility of the sex trade in hip hop discourse (a point Cheney also explores). Sharpley-Whiting examines the role of stripping and the strip club in hip hop's visual iconography, insisting on the implications of its vocabulary of gender and power. She points out that, as a result, sex is constructed as transactional:

Women purposefully use what they have to get what they want... in the same way that men use money for all and sundry deal brokering... Sex becomes as easy standby, a helpmate in the search for power for those who feel legitimately disempowered. $(143,144)$

Pimps Up, Ho's Down is concerned to point out that playing the patriarchal system in this way works only for a privileged few, and then at a cost. Keeping the exploitative system intact, such complicity has profound implications for all women, and in Sharpley-Whiting's argument, particularly for "hip hop generation young women and girls", who "appear to be rummaging around a junkyard of race and gender stereotypes for alternatives to systematic practices and biases in media, in their communities, and in their relationships, which have devalued them" (144).

Those who take Sharpley-Whiting's point, as I do, that representations of young black women in hip hop will and do have an effect on the lives of young black women - that discourse has an organic relationship to 'real life'—will be convinced by her conclusions, as I am. However, I suspect that readers less sympathetic to the underlying principle will want additional evidence. While her demonstration of the meaning of hip hop representations is impeccable, Sharpley-Whiting tends to link these representations to 'reality' by assertion, not demonstration. For example,

\footnotetext{
${ }^{1}$ http://www.pimpsup.com (accessed 26 November 2007).
} 
her conclusion about the promotion of transactional sex is that such apparent empowerment

... is a perversion of freedom, as it draws its cache not from politics but from the wells patriarchy has left exclusively to women: sex and beauty... But sex and beauty as trade commodities are depreciating assets. And for young black women as a group what accrues are harrowing statistics on sexually transmitted infections (STI), unwanted pregnancy, elective abortion as birth control, poverty, and incarceration. (147)

While this is a crucial point, it is not demonstrated, coming as it does as the final sentence of its chapter. Where the book's thesis is most compellingly proven is in the discussion of the rape case of rapper Mystikal, who videotaped a gang rape he orchestrated as punishment when a woman defrauded him (72-75). Thus SharpleyWhiting holds hip hop accountable for its representations of young black women, arguing that it facilitates sexual abuse by contributing to a culture where black women are viewed as commodities. As part of her thesis, she explores the racialization of black women's bodies and the race politics of dominant notions of beauty.

Pimps Up, Ho's Down is concerned to do more than blame, however. SharpleyWhiting also engages with black women's complicity in masculinist constructions of women, including in the role of groupie. In addition, she takes care not to reproduce a discourse that sees black masculinity as rampantly sexual and violent. The point that black men bear the brunt of responsibility for abusive behavior that is more appropriately shared is most important. She discusses the ways

...black males...p predictably become poster boys for sexual impropriety in America's high-stakes battles over morality and (white) innocence. For example: Tupac Shakur and Mike Tyson become synonymous with our exorcising of demons over date rapes rather than William Kennedy Smith, a well-known serial date rapist who media pundits concluded was an "unlikely candidate for the rapist's role"; Clarence Thomas with sexual harassment rather than serial harasser Senator Robert Packwood; O.J. Simpson with domestic violence rather than all-star baseball player Steve Garvey... (70-71)

This is an extremely apt comment. It is germane not only because it accurately holds whites responsible for the ways they perpetuate systems of oppression; it is also necessary for Sharpley-Whiting to indicate that she is not furthering this agenda because, as Cheney details in more historical depth, black women have carried the additional burden of being accused of complicity in these systems. So when Sharpley-Whiting stresses the link between what is manifesting in hip hop, and American culture more broadly, she is providing a context for hip hop's race and gender dynamics as well as engaging productively with the difficulties faced by black women in this system. As a member of the hip hop nation, too, she is concerned to be fair to hip hop's relationship to its society:

Hip hop is not a culture of violence. American culture, however, thrives on aggression. Violence... is seen as a viable alternative, one that has been sanctioned, institutionalized, and unilaterally practiced in the United States... Violence in hip 


\section{N. Distiller}

hop is a manifestation (and an easy scapegoat) for a much more prevalent American violence that much of (white) America would rather ignore. (75)

Both Sharpley-Whiting and Cheney are careful to locate their critique of black men in context. Both books become examples-in-action of black women's double bind that both write about. Cheney locates the genesis of this "race first" (107) double bind in slavery, as part of her examination of the role of this history in providing motives and metaphors for the expression of an emasculated black masculine identity. She points out how the history of slavery has been represented by black nationalists as a history of the emasculation of black men. The submission and passivity of male slaves and the development of a "slave mentality" is exaggerated in this version of history, which Cheney calls "a masculinist reading of the slave experience" (46). One implication of this version of history is the fiction that black women colluded, and continue to collude, with The Man, to keep black men down. In this story, black women benefit from the system of white patriarchal domination. In the face of the sexual, emotional, and economic suffering borne by black women in the West's history, this construction of race and gender relations is particularly pernicious.

Cheney is interested in the history and content of black nationalist masculinity, rather than in the consequences of hip hop's gender representations for women, as is Sharpley-Whiting, although Cheney also addresses women's complicity in the development of the version of black masculinity represented in hip hop. Cheney's book begins with an engagement with the definition of black nationalism, taking into account its powerful identity politics as a factor in its current popular cultural manifestation. She coins the term "raptivists" to describe a group of rap nationalists who emerged from the hip hop scene in the mid 1980s. Cheney's main thesis is that these artists belong to a tradition of American black nationalism that began in the nineteenth century. She shows in convincing detail how and why this tradition expresses the anxieties and desires of a hegemonic heteronormative masculinity, one that is concerned with accruing to itself the patriarchal rights afforded to white masculinity. "Less ... a politics of liberation than ... a politics of substitution," where what is sought is the replacement of white patriarchy with black, raptivism is "the postmodern revisioning of black nationalism as a politics of masculine protest" (99). This discourse of resistance, underpinned by an often misunderstood slave theology, authorizes violence as a legitimate way to reclaim black male power. Following bell hooks, Cheney calls this an "it's-a-dick-thing" masculinity (see, for example, 64).

Thus the sexual politics of raptivism are an extension of the sexual politics of black nationalism, where an emasculated black masculinity is recouped through a language of violence that uses women and black homosexual men as its constituting Others. Lesbians receive a passing mention, as unthreatening to dominant masculinity (a debatable assertion, as the high level of punitive violence against black lesbians in South Africa attests) and therefore allegedly not relevant to the dynamics of black nationalism or the raptivism it influenced. In contrast, Sharpley-Whiting pays more attention to lesbians in hip hop, examining the performances of "lesbianism" in strip 
clubs and videos. In the process of addressing the implications for lesbians of hip hop's gender dynamics, Sharpley-Whiting making it clear that there are lesbians in the hip hop nation, and raises some of the issues faced by lesbian performers of hip hop.

Although Cheney points out that the rising popularity of gangsta rap in the early 1990s put a stop to the conscientizing politics of raptivism, she also posits a continuity between raptivism's performance of masculinity and that of its more rapacious offspring. Cheney provides insights into gangsta rap's posturing, which she shows has its genesis in the anti-slavery black nationalist discourse of the nineteenth century, via its manifestation in the Black Power movement. Cheney also explores the influences of the Civil Rights movement on the members of the hip hop nation. She stresses its centrality to the development of rap nationalism, as the hip hop generation responded to and reacted against its parents. The fact that hip hop developed as a nationalist discourse of protest is indicative, she suggests, of the crisis in post-civil rights African American political leadership.

Supplementing her awareness of raptivism's race/gender political history, Cheney addresses the possibilities and limitations of using a commercial music form for activist purposes. She also suggests that commercial artists operate under the kind of constraints that preclude coherent and consistent activism. Many raptivists, she says, were not trained organizers, and carried an enormous burden in being made representative of and accountable for youth culture by the media and academy. She concludes that raptivism failed to sustain itself because it was not linked to a movement. As a cultural moment, it could not effect political change, although it does reveal the ongoing valency of the politics, and the gender politics, of black nationalism.

In addition to a thick historical understanding, Cheney offers excellent readings of raptivist lyrics. She focuses on specific, seminal raptivist artists, especially Ice Cube, KRS-One, Paris, and Public Enemy-as a group, and as individual artists Chuck D, Flavor Flav, Sista Souljah, and Bill Stephney. Her analysis of the formation of Public Enemy is compelling and sophisticated. She points out how the development of the group's political stance involved a complex combination of the education of its members and some canny marketing decisions, illustrating her argument about the simultaneously enabling and constraining power of capitalism.

Cheney concludes by mentioning the work of organizations that do successfully combine hip hop and activism. While I began this review by stating that both books' theses have wider relevance than their American locations, Cheney's closing anecdote allows for a consideration of the specificity of hip hop's nationalist inheritances. One of the activist organizations she mentions, the Black August Hip Hop Collective, brought a group of rappers to South Africa to attend the 2001 United Nations World Conference on Racism in Durban. The intention was to educate the rappers themselves, and so to affect their work, and their audience. Cheney provides an account of what happened:

South African journalists and students fired away with a series of hard-hitting questions... "They really wanted us to be accountable for some of the things that 


\section{N. Distiller}

were happening in the U.S ....," Kweli recalls. Among the highlights of the media frenzy was the story of a young woman who delivered an account of her personal hardships and then wondered aloud how the panelists, both as Americans and as rap artists, could solve her problems. Another attendee was offended by the hypocrisy of American rappers whose lyrics routinely focused on living in poverty when the cost of their jeans exceeded the average monthly wages of black South Africans... Adofo characterized the event as being reminiscent of a firing squad. "People were looking at them like I want you to fix my problems, you rich American," he said. (163-64).

In the course of her analysis, Cheney points out how black nationalism constructed a version of Africa for use in its own imagined community. Here are continental Africans holding African Americans accountable for the shared Africanness the latter deploy for their identity politics. What happens? The Americans behave like, well, Americans, placing themselves at the center of all discourse and responding with bewilderment to their ambivalent South African reception. The "lesson" they learn from this experience is that they should patronize their less fortunate brethren:

Talib Kweli was ... inspired by the developments in South Africa. "That experience helped me define my role," he admits. "Because [growing up] I had access to certain resources like food, shelter, and education, I have to use those resources to help my people in general all over the world." (164)

Once again, someone from the West casts himself as rescuer of the unfortunate Rest. The colonial implications of this attitude are perhaps another aspect of African American nationalist history as it develops in the hip hop nation's neo-liberal globalized context.

If you want to read only one of these two books, read Cheney's. It is the better written, more original, and more detailed. However, together both texts offer a fascinating and sobering view on the current gender politics of one of the most powerful global youth cultural phenomena and on American culture, gender, and race relations. 